\title{
Tourism as a factor of development
}

\author{
A. Ntibanyurwa \\ Department of Economics, University of the Western Cape, Cape Town, \\ South Africa
}

\begin{abstract}
If well exploited and closely linked with other sectors of the economy, tourism is believed to serve as an engine of growth. This paper shows how the tourism sector can be a factor of development by offering diverse job opportunities and by increasing foreign earnings which in many nations are used to boost other economic activities. Activities that are developed as a result of tourism include among others: entertainment, transportation services, craft rental and sales, tour guides, restaurants, hotels, beach manicures and pedicures and many more. These activities are interlinked with financial influx. From a trade perspective, the paper argues from reviewed literature that tourism in many developing nations contributes to foreign earnings more than many other economic sectors regarded as main export-oriented without facing the same trade restrictions. Tourism has a powerful multiplier effect through which it contributes to development. Through consumption of local tourism products and other local but non-tourism products, tourism can perform as a means for development of many small businesses. The paper concludes that the tourism sector needs to be sustainable in order to successfully play its role of development factor.

Keywords: development, economic growth, foreign earnings, GDP, income, job, linkages, multiplier effect, tourism, trade.
\end{abstract}

\section{Introduction}

The contribution of tourism sector to development needs to be clearly explained to allow countries to invest into tourism. The objective of this paper is to demonstrate how tourism can be considered as a development factor. The approach used is a literature based analysis.

From economic perspective, the paper shows how tourism contributes to boost economic growth, therefore to development. Through its powerful linkages 
with other sectors, tourism stimulates revenues in many sectors. Factors such as investments, income, trade, contribute to economic growth which is the base of any development. Tourism plays a considerable role in those factors.

The remainder of this paper is organised as follows. The next section presents the role of tourism in economic growth. In this section, three main aggregates (gross domestic product (GDP), trade, income and employment) are tackled. The third section explains the impact of tourism on development through the multiplier effect. The fourth section deals with tourism sustainability while the last section concludes the paper.

\section{Tourism role in economic growth}

The role of tourism in economic growth can be observed from different angles. Tourism contributes to increasing foreign earnings through the mechanism of tourists spending in the visited country. Through its strong backward and forward linkages, tourism contributes directly and indirectly to the development of nations. This can be demonstrated using transitivity logic whereby we assume that if tourism contributes to economic growth; and economic growth contributes to development; therefore tourism contributes to development. In this paper, the contribution of tourism to economic growth is analysed using three major aggregates:

\subsection{Tourism and GDP}

There are several economic activities that should be in place in order to allow proper functionality of tourism. The construction phase of tourism calls upon engineers to build infrastructures. In this case, engineers' activity is stimulated by the idea of implanting tourism business with financial influx. If wealth is distributed to many people, government revenues can also increase as they depend mainly on taxes from residents who earn money from different activities related to tourism directly or indirectly. This contributes substantially to GDP as this is composed by all incomes earned by private and public institutions as well as households.

Being a fast-growing industry in the world, tourism brings economies to benefit from its positive impacts such as ameliorated infrastructures and investments (Saayman et al [1]). Using suitable infrastructures and investments in tourism, other economic sectors can develop. For instance, if we consider the case of agricultural produce, infrastructures that serve tourists can be used to connect regions and ease delivery of goods. This idea is also supported by Hernández [2] who states that new investments used for building up tourism favour regional economy. This can be observed by means of creating jobs and generating income during this construction phase. Although the nature of job created is mainly for short term, still it changes people's lives during that period and allows money to circulate in the area. During the operational phase, tourists' spending flow more permanently into local region and stimulate diverse linkages with other economic sectors, which is also beneficial to economic development.

Taking GDP as a yardstick for measuring development and the role of tourism, a study by WTO [3] has shown that international tourism arrivals have 
grown bigger than the GDP, and that the growth of GDP was positively linked to the growth of tourism. In years when world economic growth exceeds $4 \%$, it was a result of a growing tourism industry above the GDP growth rate. The decrease in tourism resulted in the decrease of GDP. During the period of 1975-2000 when GDP grew at $3.5 \%$, the growth rate of tourism was 1.3 times faster than GDP, representing an average of $4.6 \%$ a year WTO, [3]. A concrete case of Mauritius can be given. Owing to the development of tourism, Mauritius economy has improved steadily moving from a poor country in 1968 to middle income country in 1997 . GDP per capita grew from $\$ 219$ to $\$ 3543$ respectively in 1968 and 1997 [4]. California economy is another example where tourism has played a significant role. Visitors spending for the year 2005 amounted at US\$ 88.1 billion, which reflects an increase of 7.6\% from previous year (Zucker [5]). Another successful example in tourism is the Caribbean region, where tourism receipts represent $14.8 \%$ of the region's total GDP. This is expected to increase up to $16.5 \%$ of GDP by 2014 (Chaves [6]). It is worth noting that even without pre-existing tourist attractions (sea, sand, sun and other natural attractions) countries can still exploit tourism benefits. In our view, countries without natural attractions can organise something different to attract tourists. For example, a unique cultural attraction can be offered, way of living and socialising can be presented, local dishes can be introduced etc. For countries with similarities in tourism products particularly those in same region, a comparative advantage approach can be used to differentiate their products to attract tourists.

To analyse if tourism is appropriate for Least Developed Countries (LDCs), Brau et al [7] investigated in 1980-1995, the relative growth performance of 14 "tourism countries" within a sample of 143 countries. Their findings reveal that "tourism countries" grow considerably faster than other subgroups taken into account in their analysis (OECD, Oil, LDCs, and Small). This reveals the importance of tourism in economies.

Likewise, the impact of tourism on economy depends on the kind of goods that tourists demand (accommodation, food, transport, and entertainment). The demand for these goods and services has a positive impact on tourism-connected industries that produce these items for tourist satisfaction. The production in these industries will increase to respond to a growing demand from tourism, therefore inducing a rise in income for the supply industry (Juan et al [8]). The increased income positively impacts on government revenues by means of taxes which also contribute to economic growth via governments' interventions. Besides taxes from tourism employment and businesses, tourism increases government revenues by direct levies on tourists (departure taxes), indirect taxes and duties on goods and services offered to tourists (UNEP [9]). The contribution of tourism to economic growth can also be analysed from a trade perspective.

\subsection{Tourism and trade}

From a trade perspective, tourism in many developing countries makes a greater contribution to foreign earnings than other sectors considered as major export- 
oriented without facing the same trade barriers (Williams [10]). Tourism sector in general does not have as much restrictions as other export-oriented activities where countries try to protect local production by imposing high entry fee for imported products. This is due to the fact that tourism goods and services are consumed in the country provider. This is favourable when considering trade advantages that may be spread to local economies instead of benefiting outsiders.

Looking at international evidences, recently tourism accounted for $65 \%$ of service sector in Argentina. In Brazil, tourism generated revenues of more than $\$ 5$ billion. Tourism in Peru has risen significantly reaching more than $\$ 1$ billion in 2000 and accounting for over 12\% of Peru's export revenue (Noelia [11]). Of the LDCs, only Tanzania was a significant tourism destination in 2000 generating \$ 570 million in visitor expenditure. Cambodia, Nepal and Uganda were the only other countries to generate more than US\$ 100 million (Benavides [12]; UN [13]; Aguayo, et al [14]). In terms of the proportion of exports represented by tourism receipts, the highest for the LDCs was again Tanzania with nearly $35 \%$, followed by Vanuatu (33\%) and the Gambia (24\%) (Benavides [12]). Tourism represented over $100 \%$ of the export revenues of many Caribbean countries (WTO [15]). In California, travel spending in 2005 created \$ 1.9 billion in local taxes and $\$ 3.4$ billion in state taxes. For every $\$ 100$ spent in travel, \$ 31.74 income was generated; \$ 2.19 local tax and 3.82 state tax revenues were created in 2005 (Zucker [5]).

The performance of tourism in the above countries proves how important the sector is as regard to development. Receipts for those countries serve to achieve many objectives among others developmental objectives. Figures for 2002 indicate that international tourism receipts amounted to US\$474 billion (WTO [16]). It is also estimated that travel and tourism contribute $\$ 3.7$ trillion to global economy.

Looking at tourism receipts per region, data from WTO [3] reveal that in 2004, Europe accounted for US\$ 326,693 million, followed by America with US\$ 131,682 million, Asia and the Pacific with US\$ 124,960 million and Africa with only US\$ 18,335 million. All these regions have increased significantly their receipts compared to the previous year where the amounts were US\$ 282,913 million; 114,104 million; 94,855 million and 15,494 million respectively.

Another interesting point regarding tourism and trade is that wherever tourism business starts, burgeoning related activities follow with their impacts on local economy. For instance, a holiday hotel construction attracts businessmen to implant to the proximity of the hotel for serving tourists different needs. This tourist business calls upon taxi and bus owners to offer their services for transfers, excursions and round trip. Contractors are also needed for their service regarding the vehicle for hotel facilities. Musicians and artists are also employed to entertain hotel customers. Artisans also seize the opportunity to expose and sell their products to tourist as souvenirs and many others activities.

The contribution of tourism to economic development is recognised by empirical studies. Data from the World Tourism Organisation in 2003 show that tourism receipts represented $6 \%$ of export of goods and services worldwide 
(Freytag and Vietze [17]). Considering service exports only, the share of tourism demonstrates an increase of $30 \%$ (WTO [3]).

Considering the country's dependence on export, it is worth mentioning that the development of tourism can reduce a country's reliance on primary commodities as a source of export earnings and yet still develop. If a country is mainly relying for instance on agriculture exports, in developing tourism, not only it can expand its export earnings, but also avoid price fluctuation that affect primary commodities (Ennew [18]).

Successful experiences of small economies and islands that have recently become emerging tourism destinations (such as Mauritius, Maldives, the Dominican Republic and other Caribbean islands) have revealed the vital importance of building proper linkages between tourism activities and the rest of the economy. Such linkages are key factors in increasing value-added from trade in tourism services, and reducing leakages from tourism in developing countries (Benavides [19]). When economic sectors of a country including tourism develop strong linkages in a way that each industry buys and sells its inputs and outputs from other local sectors, the risk of depending on imported inputs to produce goods and services for tourist and local market can be reduced. Therefore, money meant for import can be used to serve local needs and development.

Considering tourism in LDCs, empirical studies show that tourism plays a significant role in these nations. In 2004, tourism in LDCs represented a growing $70 \%$ of service exports (WTO [3]). It is interestingly important to note that poor countries begin to value tourism activity as a source of poverty reduction. For LDCs, tourism nearly leads in economic growth, foreign exchange, investment and job creation (Freytag and Vietze [17]).

As mentioned earlier, tourism contribution to development through economic growth is viewed from different angles and in what follows, tourism impact on income generation and job creation is presented.

\subsection{Tourism impact on income generation and job creation}

The great advantage of tourism is that it is labour intensive. An increase in production is normally achieved by an increase in employment. This is beneficial for those economies that need to reduce unemployment rate. On the other side, tourism can create shock in the job market rising wages in the service sector and inducing mobility across sectors (UN [13]).

The contribution of tourism to development is explored by Eugenio-Martin et al [20] where they look at the relationship between tourism and economic growth. Using a panel data approach for Latin American countries for the period 1985-1998, their findings reveal that tourism is appropriate for economic growth of medium and low-income countries and not necessarily a sufficient factor for the developed world. This can be interpreted in terms of full employment versus unemployment. Being labour intensive, tourism is likely to be more effective in countries where unemployment prevail than in countries where the economy tends to be at full employment. More people in developing countries can be 
employed as the tourism develops while the development of tourism in the developed nations may result in using other sectors' labour force, reducing their performance.

The rapid expansion of international tourism has led to significant employment creation. For example, hotel accommodation sector alone provided 11.3 million jobs in 1995 worldwide. According to UNEP [9], tourism supports some $7 \%$ of the world's workers and the more people employed the more income distributed. In California 911,800 jobs were created from tourism in 2005, rising income of $\$ 28$ billion (Zucker [5]).

Tourism industry is mostly concerned with the provision of services. These services have a high employment component, and even a high ratio of lowly qualified personnel which favourable for LDCs. In Gambia, 30\% of the workforce in 2001 depended directly or indirectly on tourism. In Small Island Developing States, percentage ranged from $83 \%$ in the Maldives to $21 \%$ in the Seychelles and 34\% in Jamaica (UNEP [9]).

Employment in tourism is also linked to income workers get from the sector. A study by Corsten [21] has found that in developing countries, employees in tourism sector (such as hotels) are better off than their compatriots. These are either unemployed or employed in other sectors where they got paid little money due to low qualification. Income earned from tourism allows employees in the sector to cater for their family needs and therefore contributing to the wellbeing of households.

To summarise the impact of tourism on development through economic growth path, the following mathematic demonstration is provided:

Suppose a simple model of economic development represented by the following equations:

$$
E_{d}=E_{g}+O_{f}
$$

and

$$
E_{g}=I_{h}+T_{r}+G_{r}+O_{f}
$$

Replacing eqn (2) in eqn (1), we obtain

$$
E_{d}=I_{h}+T_{r}+G_{r}+O_{f}+O_{f}
$$

where $E_{d}=$ economic development; $E_{g}=$ economic growth; $I_{h}=$ households income; $T_{r}=$ Revenue from trade; $G_{r}=$ Government revenues and $O_{f}=$ other factors.

When considering economic growth as important factor of development, we have explained previously that tourism contributes to economic growth by generating income to households, by increasing revenue from trade and by expanding government revenues. Following this logic and referring to the above three equations, other things remaining equal or constant, it can be concluded that: 


$$
\begin{gathered}
\text { If Tourism business } \uparrow, \Rightarrow I_{h}, T_{r}, G_{r} \uparrow \\
\text { and if } \quad I_{h}, T_{r}, G_{r} \uparrow, \Rightarrow E_{g} \uparrow \Rightarrow E_{d} \uparrow
\end{gathered}
$$

Therefore, tourism development leads to economic growth, which leads to development and allow us to assert that tourism can be considered as one of development factors.

Tourism has made an important contribution to economies of several countries that have chosen it as a development strategy. It has spill-over effects on other economic sectors as explained in what follows.

\section{Tourism impact on development through multiplier effects}

Multiplier effect refers to a change in an economic activity as a result of a change in action in some other sector (Pao [22]). Tourism multiplier is based on the assumption that tourism spending is distributed across other economic sectors (Kweka et al [23]). The idea is that tourism activity is not a separate activity but is located within the whole economic industry and is interconnected with other sectors. For instance, to satisfy tourists demand, tourism needs not only tourism products (natural attraction, tourism resorts, etc.), but also other sectors (transport, agricultural, financial and many others). In this, the presence of tourist in a location can bring foreign currency not only to visited place, but also can spread this income to other sectors which support tourism. These sectors in turn spend their revenues in other sectors and so on. This proves that tourism is an important catalyst sector. And the more developed is tourism, the more impacts it can have on other sectors as a result of multiplier effects across sectors.

The contribution of tourism to development is observed at direct, indirect and induced levels. Recent literatures (Carstensen [24]; Pao [22]) suggest that direct effect multipliers in tourism translate direct sales to income, value added, and employment linked with visitor spending in tourism sectors. Here, sectors dealing directly with tourists are the first beneficiaries of tourist spending. These are hotels, restaurants, tourism resorts, to name but a few. However, the benefits derived from their services to tourists do not stop there, they continue in other sectors impacting on their growth and on the country's development in general.

Indirect effects represent changes in sales, income and employment within industries that have backward linkages (supplying goods and services) with tourism. Benefits received directly from tourists are extended to other sectors by the spill over effect and allow these indirectly linked industries to develop as result of tourism activity.

Induced effects reflect increased sales in local industries as a result of households spending from tourism and connected industries. This spending develops sectors such as housing, food, transport, education and many goods and services that consumers demand. This process of spending and respending generates again sales, income and employment throughout the region's economy (Sugiyarto et al [25]). 
By means of direct, indirect and induced effects, changes in tourist spending can affect almost every sector. The degree of indirect and induced effects depends on the propensity of businessmen and households in the region to buy and consume locally produced goods and services. The more goods and services are purchased from locals, the more the region can benefit from tourism spending. This phenomenon of increasing income all over other sectors as a result of initial and subsequent tourist spending is known as "multiplier effect". Eventually, it is via the multiplier effect that tourism contributes to development as presented in the diagram below.

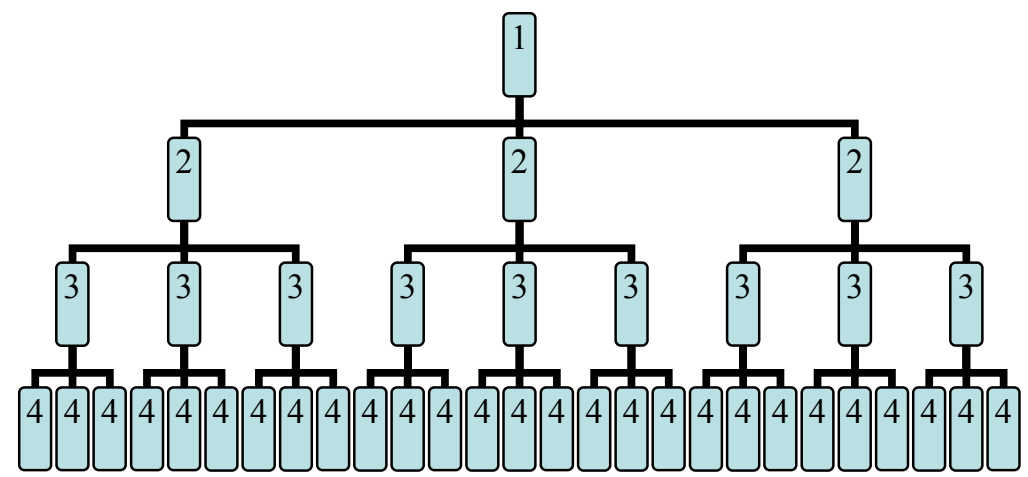

Figure 1: $\quad$ Tourism multiplier effect.

The above diagram presents four different levels as follows:

1. Tourism sector: It is a departure point where investment is made for tourism activity. This starting point corresponds to the constructional phase of tourism where income is distributed to different people and organisations who are involved in this phase. At this stage, the impact on development is not yet big as businesses are supporting investment costs.

2. Direct effects: At level two of the diagram, tourism activity has started running and cash earnings directly from tourists are being received by tourism operators who deal directly with tourists. This operational phase allows money to circulate more permanently into the economy.

3. Indirect effects: Indirect effects are being observed at level three where industries supplying tourism business are flourishing as a result of tourism activity. These industries spread income to their workers and to businessmen they entertain with as wages or price of purchased goods.

4. Induced effects: At this level of induced effects, different people earn incomes either directly or indirectly from the tourism business. These incomes are spent in other economic activities and allow the money to circulate into the whole economy.

At each level of the diagram, there is an impact on the economy in the sense that the first person who receives the tourist dollar does not keep it unproductive, he or she circulates it by ways of running business and distributing wages to 
employees, who in turn purchase goods and services to others, and these others do the same and so on and so on, until the money reaches negligible value. This results in the fact that the impact of tourism activity on the economy is bigger than the initial tourist spending. The more the economy is locally integrated, meaning having strong linkages from within, the more it can benefit from tourism sector. Consequently, tourism impact on development is well explained by the multiplier effect. In order for tourism to contribute successfully to development, it needs to be sustainable. It means develop in a way that takes into account future needs for development and minimise potential leakages as explained in the next section.

\section{Tourism and sustainability}

The concept of sustainable tourism is used in the context of achieving economic growth without damaging the natural and built environment and conserving the culture of local communities (Kamamba [26]). Within this concept, it is expected that high quality product are derived from tourism. This is made possible by responsible management of resources that leads to acceptable conservation of the tourism product. If tourism attractions are not well maintained, they can lead to the degradation of the environment and deterioration of tourism product especially natural attractions. Given that tourism cannot develop alone, complementary sectors also need to be maintained in order to develop and sustain tourism activity. For example, tourism needs safety, good services, good infrastructure, advertisements of place of interests and services offered and so on. Failure to maintain tourist attractions and complementary services can reduce not only income from tourists but also destroy the strong link between tourism and other sectors.

Tourism as noticed (Williams [10]) can be good for development when it engenders a strong inflow of foreign exchange and positive inter-sectoral linkages which promote growth. But, tourism can also be bad for development if there is a negative inter-sectoral linkage (if developed at the expense of other sectors such as agriculture and manufacturing), strong leakage through high imports of food and beverages, and little value-added to GDP (Williams [10]; Mope [27]). The argument of tourism having negative impact on economy because it develops at the expense of other sectors is arguable. In our opinion, a country should invest in the sector with high rate of returns. If for instance tourism is competing a land with agriculture, instead of giving that land to local people for agriculture purposes with little productivity, it is better exploiting it for tourism if this is where more revenues are expected. And government revenues obtained in exploiting efficiently a land for tourism can serve to develop the remaining agriculture land for instance by supplying fertilisers to farmers.

Given its strong linkages with other economic sectors, tourism development needs not to be taken in isolation. It is important to develop tourism together with complementary sectors such as construction, security, medical facilities (for emergency), manufacturing, agriculture, etc. It can be ineffective to develop tourism attractions leaving behind complementary goods and services. A good 
service provided in a friendly and peaceful place can always attract tourist demand.

It is predictable that if the development of tourism is not controlled, it can result in strong leakages than benefiting local economies. For instance, private investors can use imported goods to serve tourists, while the same goods are produced locally. On this, we suggest that the development of tourism be controlled by the government. Private and public investments can take place but for tourism to benefit local economy, governments need to keep an eye on its development. This can be done by promoting local products and stimulating local people to produce quality goods and services. Investors should not be allowed to import locally produced goods. To maximise benefits from tourism, government and local investors can try to get ownership of tourist goods and services such as air flights. Transport means represent a large proportion of tourist budget. Information is also important as regard to tourism promotion. Tourists worldwide need to know what a country or a tourist place has to offer. A failure in providing such information can attract nobody, as no one knows about what is offered in that place. Information can be spread using modern technology where everyone interested can access to it. For example advertise on internet and updating the website, allowing people to use internet facilities for services such as bookings (flight, hotels, etc.), visa information etc.

In summary, it can be said that tourism is a potential development factor, provided that it maintains its positive strong linkages with other economic sectors, and significantly reduces leakages at low level.

\section{Conclusion}

From construction to operational phase, the paper demonstrated that tourism is potentially a factor of development contributing to economic growth. Using economic growth as main factor of development, it has been observed that tourism contributes significantly to boost countries' economic growth and this is mainly done through the multiplier effect of tourism. Being at the centre of development, activities related to tourism evolve in the same way benefiting from its positive impacts but also suffering from its negative effects. With tourism development, opportunities for job creation, income generation, increased export earnings, etc. are immense. However, tourism should be sustainable to play successfully its role of factor of development. The role of tourism in economic development is undoubtedly big, but measurement of tourism economic impacts remains challenging. In our future work, we will investigate on how to accurately measure tourism economic impact especially in developing countries.

\section{References}

[1] Saayman, M., Saayman, A., \& Rhodes, J.A, Domestic tourist spending and economic development: the case of the North West province. Development Southern Africa, 18 (4), October 2001. 
[2] Hernández, M.R., Impact of Tourist Consumption on GDP. The Role of Imports. Department of applied economics, University of la Laguna 2001.

[3] WTO, Tourism Market Trends, 2005 Edition - Annex, www.worldtourism.org/facts/menu.html.

[4] The economy of Mauritius. www.intnet.mu/iels/eco mau.htm.

[5] Zucker, R., Tourism continues to boost California economy, 2006.

[6] Chaves, G.L., Caribbean Regional Sustainable Tourism Development Programme. Regional sustainable tourism policy and cycle, 2003.

[7] Brau, R., Lanza, A. \& Pigliaru, F., How fast are the tourism countries growing? The cross-country evidence, Fondazione Eni Enrico Mattei Working Paper Series, NOTA DI LAVORO 85, 2003.

[8] Juan, L.E.M., Noelia, M.M. \& Ricardo, S., Tourism and Economic Growth in Latin American Countries: A Panel Data Approach, 2004.

[9] UNEP, Economic impacts of tourism. Production and consumption branch, Tourism, 2002. Www.unepic.org/pc/tourism/susttourism/economic.

[10] Williams, M., The Political Economy of Tourism liberalization, Gender and the GATS, 2003.

[11] Noelia, M.M., Tourism and Leisure in Latin America, 2003.

[12] Benavides, D.D., Tourism Policy and Economic Growth. The Sustainability of International Tourism in Developing Countries. Berlin, 6-7 March 2001.

[13] UN, Third United Nations Conference on the Least Developed Countries. Business Sector Round Table. Brussels, 16 May 2001.

[14] Aguayo, E., Alvarez, L. \& Gardella, R. J., External Trade, Tourism and Economic Integration in Latin America. Working Paper Series Economic Development, (70), 2003.

[15] WTO, Pro-Poor Tourism Info-Sheets. Economic data on the importance of tourism in the poorest countries, (7), 2001.

[16] WTO, Yearbook of Tourism Statistics, World Tourism Organisation, Madrid, 2003.

[17] Freytag, A. \& Vietze, C., International tourism, development and biodiversity: First evidence. Friedrich-Schiller University Jena, Germany, 2006.

[18] Ennew, C., Understanding the Economic impact of tourism. Som nath Chib Memorial Lecture, February $14^{\text {th }}$ 2003. Christel Dehaan Tourism and Travel Research Institute, 2003.

[19] Benavides, D.D., A Think Tank to Show a Way Forward. International Symposium on Liberalization and Trade in Tourism Services, Madrid 2223 March 2004.

[20] Eugenio-Martin, J. L., Morales, N. M. \& Scarpa, R., Tourism and Economic Growth in Latin American Countries: A Panel Data Approach, Fondazione Eni Enrico Mattei Working Paper Series, 2004.

[21] Corsten, R., "Multilateralism at a crossroads" Trade, Tourism and progressive poverty alleviation. WTO public symposium, Geneva, 25 to 27 May 2004. 
[22] Pao, J.W., A Review of Economic Impact Analysis for Tourism and Its Implications for Macao. Monetary Authority of Macao, 2005.

[23] Kweka, J., Morrissey, O. \& Adam, B., Is tourism a key sector in Tanzania? Input-Output analysis of income, output, employment and tax revenue, 2003.

[24] Carstensen, F.V., The 2001 Economic Impact of Connecticut's Travel and Tourism Industry. University of Connecticut, 2003.

[25] Sugiyarto, G., Blake, A. \& Sinclair, M.T., Tourism and Globalization: Economic Impact in Indonesia. Annals of Tourism Research, 30 (3), pp.683-701, 2003.

[26] Kamamba, D.M.K., The challenges of sustainable cultural heritage/community tourism. Second African peace through tourism conference, Dar es Salaam 7-12 December 2003.

[27] Mope, J., Ecotourism in the Less Developed Countries. Journal of Travel Research, Spring, pp. 41-55, 2004. 